\title{
Functions and Applications of Plant Growth Promoting Bacteria (PGPR) in Highly Technified Crops
}

\author{
Ortega $\mathbf{R}^{1 *}$, Miralles $\mathbf{I}^{1}$, Domene $\mathbf{M} \mathbf{A}^{2}$, Sánchez-Marañón $\mathbf{M}^{3}$ and Soriano $\mathbf{M}^{1,4}$ \\ ${ }^{1}$ Departament of Agronomy, University of Almería, Spain \\ ${ }^{2}$ Department of Health and Nutrition, Experimental Station of Cajamar Foundation, Spain \\ ${ }^{3}$ Department of Soil Science and Agricultural Chemistry, University of Granada, Spain \\ ${ }^{4}$ University of Granada Junta de Andalucía Pfizer Center of Genomics and Oncological Research, Spain
}

Submission: October 21, 2016; Published: October 30, 2017

"Corresponding author: Ortega R, Department of Agronomy, University of Almeria, Spain, Tel: +34686624073; Fax: +34950015939; Email: rortega@ual.es

\begin{abstract}
The need of higher agricultural productivity in recent decades has led to a great technification in crops. However, this had significant environmental costs due mainly to the indiscriminate use of fertilizers and pesticides. In response, a new trend seeks to establish more environmentally friendly cultivation methods where plant-growth-promoting bacteria (PGPR) can play a key role. PGPR influence a large number of plant-growth and developmental factors ( $\mathrm{N}$ and $\mathrm{P}$ assimilation, phyto hormones, etc)) and help protect against other harmful organisms (antagonistic and bio-control effects, ISR and SAR). Thus, cultivation of PGPR for introduction into crops can result in large commercial opportunities. However, the implantation of these microorganisms is complex, making research on microorganisms-plant interactions a topic of great current interest.
\end{abstract}

Keywords: Plant growth promoting bacteria; NP assimilation; Phytohormones; Antagonism; bio-control; ISR \& SAR

\section{Introduction}

Human and animal feeding needs have led to rapid technological development in crops during the recent decades [1], even allowing the crops to become practically independent of the environment when using greenhouses where inputs and outputs and multitude of environmental factors are controlled. This has great advantages, since it allows, on one hand, to control a multitude of aspects related to the crops and, on the other, to minimize harmful external vectors such as insect pests that can devour plants and transmit diseases by viruses, bacteria and fungi. Crops are controlled under the most aseptic conditions possible and in fact there are soilless cultivation techniques (hydroponic crops) or in artificially created and periodically sterilized soils. In these cases, the inputs of nutrients to plants are generally provided by fertirrigation with inorganic fertilizers dissolved in the irrigation water.

However, intensive use of fertilizers and pesticides has significant environmental ramifications, leading to a new trend to reduce the application of synthetic fertilizers and pesticides. For this, studies are valuable on the beneficial effects of certain microorganisms and the use of fresh vegetable remains and compost-like amendments [2], which in turn introduce large amounts of microorganisms into the soil.

Although microorganisms can be found everywhere in soils, it is close to the roots of plants where concentrations can rise 10 to 100 times higher (Weller and Thomashow, 1994). This area is known as the rhizosphere, and although initially described at the beginning of the 20th century [3] like the soil zone where microbial populations are stimulated by root exudates (i.e. amino acids and sugars), this concept has been extended to the soil zone around roots where physical, chemical, and biological properties have changed due to root growth and activity [4]. The organisms present in therhizosphere include bacteria, fungi, protozoa and algae, although the bacteria are the most abundant and are selected by plants according to their needs. 
On the other hand, microorganisms not only benefit from the root exudates but also have an ecological niche, where they can develop and even (in the case of endophytic bacteria) a place inside plant cells where they do not have to compete with any other microorganism [5]. Antoun \& Kloepper [6] estimated that about $1-2 \%$ of the rhizosphere bacteria have a special role in strengthening and protecting plants. This group of bacteria is known as plant-growth-promoting rhizobacteria (PGPR) and species of the genera Pseudomonas, Azospirillum, Azotobacter, Klebsiella, Enterobacter, Alcaligenes, Arthrobacter, Burkholderia, Bacillus, Rhizobium and Serretia have been described within this group $[7,8]$.

\section{Effects of PGPR}

PGPR affect plants both directly and indirectly. PGPR directly provide the plant with substances that are synthesised by the bacteria or facilitate the absorption of certain plant nutrients from the environment. The indirect promotion of plant growth occurs when PGPR prevents the deleterious effects of one or more phytopathogenic microorganisms [9-13].

\section{Biological fixation of $\mathbf{N}$}

$\mathrm{N}$-fixing microorganisms can live free or in symbiosis with some plants, especially with legumes where they form nodules in their roots [14]. These microorganisms take the atmospheric $\mathrm{N}$ and supply it in the form of compounds assimilable by the plants and in turn receive carbohydrates from the roots $[15,16]$.

\section{Solubilization of phosphorus}

Together with $\mathrm{N}$ and $\mathrm{K}, \mathrm{P}$ is another of the macronutrients of plants. Although agricultural soils usually have sufficient amounts of $\mathrm{P}$ due to inputs from fertilizers, much of it is usually in insoluble form not available to plants. However, there are some microorganisms capable of converting insoluble phosphorus to soluble forms such as orthophosphates [17-19].

\section{Production of stimulants of plant growth}

There is evidence that PGPRs produce phytohormones such as auxins, gibberellins, cytokinins, and ethylene that influence a large number of processes such as stem and root growth, flowering, and fruit development [20-23].

\section{Antagonistic activity and biocontrol agents}

According to Beattie [24], bacteria that reduce the incidence of plant diseases are considered biocontrol agents, whereas those that exhibit antagonistic activity against plant pathogens are defined as antagonists [25,26]. The following actions can be highlighted within these activities.

Synthesis of hydrolytic enzymes: such as chitinases, glucanases, proteases and lipases that can lyse pathogenic fungal cells $[27,28]$.

Production of siderophores: Most of Fe in the soil is usually in insoluble forms and in Fe-limiting environments PGPRs can produce siderophores, which are iron chelating compounds that trap available iron and provide it to plants, thereby promoting their growth [29-31]. It also has an antagonistic effect by preventing other harmful bacteria and fungifrom taking $\mathrm{Fe}$ from the soil. Bacterial siderophores can be classified into four types (carboxylate, hydroxamates, phenol catecholates and pyoverdines) [32].

Production of antibiotics: According to Haas \& Défago [33] there are 6 classes of antibiotic compounds produced by PGPRs and related to the control of root diseases: phenazines, phloroglucinols, pyoluteorin, pyrrolnitrin, cyclic lipopeptides, and hydrogen cyanide. Besides other antibiotics such as polymyxin, circulin and colistin, are active against pathogenic bacteria and fungi [27].

\section{Induced systemic and systemic acquired resistance (ISR \& SAR)}

These are two independent phenomena but in plants they provoke an immune response to attacks by pathogens. ISR consists of a self-plant resistance induced by non-pathogenic rhizobacteria or PGPR [34-36]. SAR is a resistance activated by exposure to a pathogen. ISR and SAR act by different metabolic pathways. While induction of SAR is through salicylic acid, ISR requires jasmonic acid [34]. ISR-mediated protection is significantly lower than that produced by SAR [37]. Nevertheless, both types of protection can occur simultaneously with a higher effect than each separately [38].

\section{Commercial Application of PGPR}

As can be concluded from the above, PGPR applications can be multiple and generally result in an environmentally more sustainable alternative than chemical fertilizers and pesticides [39-42]. According to Nakkeran et al. [43], optimal PGPR for commercialization must have the capacity to compete with other microorganisms, increase plant growth, have a broad spectrum of action, and be resistant to heat, UV radiation, and oxidizing agents. Despite that species of Bacillus, Enterobacter, Klebsiella, Azobacter, Variovorax, Azosprillum, and Serratia [6] have been applied commercially for several decades and new studies in laboratory are promising, the effects in crops are not totally satisfactory $[44,45]$.

For example, PGPR use as fertilizers involves losses during aerial application, due to environmental factors, runoff, etc. However, there are several options to favour the establishment of PGPR. They are often applied to plant seeds [46] and, once sown, PGPR should be able to settle in the rhizosphere by taking advantage of plant exudates. On the other hand, nano encapsulation technology can be used as a tool to protect PGPRs and allow a more controlled release of PGPR [47]. Genetic modification experiments may also improve the functionalities and establishment of PGPR [48].

Despite of the large number of studies related to the mechanisms and mode of operation of PGPR, the complexity of PGPR-plant interactions makes it necessary to expand the 
knowledge on this topic. Molecular and genetic studies [46] should allow further comprehension of these interactions in the rhizosphere and help in the development of new commercial products. Finally, these studies can be strengthened by advances in metagenomics due to recent progress in bioinformatics, refinement of DNA amplifications and computational development [49]. This will facilitate the identification of bacteria species in experimental crops and the monitoring of the time course of populations throughout the culture cycles $[50,51]$.

\section{Acknowledgement}

The authors are grateful for funding received from the Spanish Ministry of Economy, Industry and Competitiveness (MINECO) under the NACAL (CGL2015-71709-R) Project. The second author is also grateful for funding received from the Ramón y Cajal Research Contract (RYC-2016-21191) from the Spanish Ministry of Economy, Industry and Competitiveness (MINECO).

\section{References}

1. Nelson GN, Rosegrant MW, Koo J, Robertson R, Sulser T, et al. (2009) Climate Change: Impact on Agriculture and Costs of Adaptation. Food Policy Report. International Food Policy Research Institute, Washington, USA.

2. Ortega R, Miralles I, Meca DE, Gázquez JC, Domene MA (2016) Effect of organic and synthetic fertilizers on the crop yield and macronutrients contents in soil and pepper. Communications in Soil Science and Plant Analysis 47(10): 1216-1226.

3. Hiltner L (1904) Uber neuere erfahrungen und probleme auf dem gebiet der boden bakteriologie und unter besonderer berucksichtigung det grundungung Deut Landw Ges 98: 59-78.

4. McCully M (2005) The rhizosphere: the key functional unit in plant/soil/microbial interactions in the field. Implications for the understanding of allelopathic effects. In: Harper J, An M, Wu H, Kent (Eds.), Proceedings of the 4th World Congress on Allelopathy Charles Sturt University, Wagga, NSW, Australia, pp. 43-49.

5. INTAGRI (2017) La Rizósfera de los Cultivos: la Clave Oculta para el Rendimiento Sostenible de la Agricultura. Serie Suelos 32. Artículos Técnicos de INTAGRI. México, North America, pp. 1-3.

6. Antoun H, Kloepper JW (2001) Plant growth promoting rhizobacteria (PGPR). In: Brenner S, Miller JH (Eds.), Encyclopedia of Genetics. Academic Press, New York, USA, pp. 1477-1480.

7. Podile AR, Kishore GK (2006). Plant growth-promoting rhizobacteria. In: Gnanamanickam SS (Editor). Plant-Associated Bacteria. Springer, Netherlands, Europe, pp. 195-230.

8. Saharan B, Nehra V (2011) Plant Growth Promoting Rhizobacteria: A Critical Review. Life Sciences and Medical Research pp. 1-30.

9. Bowen GD, Rovira AD (1999) The rhizosphere and its management to improve plant growth. Advances in Agronomie 66: 1-102.

10. Glick BR (1995) The enhancement of plant growth by free-living bacteria. Can J Microbiol 41: 109-117.

11. Kokalis BN, Vavrina CS, Roskopf EN, Shelby RA (2002) Plant bacteria interactions strategies and techniques to promote plant growth. Plant and Soil 238: 257-266.

12. Schippers B, Bakker AW, Bakker PA (1987) Interaction of deleterious and beneficial rhizosphere microorganisms and the effect of cropping practices. Annual Review of Phytopathology 25: 339-358.
13. Schippers B, Bakker A, Bakker P, van Peer R (1990) Beneficial and deleterious effects of HCN-producing pseudomonads on rhizosphere interactions. Plant and Soil 129 (1): 75-83.

14. Werner D (1992) Symbiosis of Plants and Microbes. Chapman and Hall, New York, USA, pp. 387-400.

15. Boddey RM, Dobereiner J (1988) Nitrogen fixation associated with grasses and cereals: recent progress and perspectives for the future. Plant and Soil 108 (1): 53-65.

16. Fuhrmann JJ, Wollum AG (1989) Nodulation competition among Bradyrhizobium japonicum strains as influenced by rhizosphere bacteria and iron availability. Biology and Fertility of Soils 7 (2): 108112.

17. Chen YP, Rekha PD, Arun AB, Shen FT, Lai WA, et al. (2006) Phosphate solubilizing bacteria from subtropical soil and their tricalcium phosphate solubilizing abilities. Applied Soil Ecology 34 (1): 33-41.

18. Rodriguez H, Fraga R, Gonzalez T, Bashan Y (2006) Genetics of phosphate solubilization and its potential applications for improving plant growth-promoting bacteria. Plant and soil 287(1-2): 15-21.

19. Selvakumar G, Joshi P, Nazim S, Mishra PK, Bisht JK, et al. (2009) Phosphate solubilization and growth promotion by Pseudomonas fragi CS11RH1 (MTCC 8984), a psychrotolerant bacterium isolated from a high altitude Himalayan rhizosphere. Biologia 64 (2): 239-245.

20. Ahmad F, Ahmad I, Khan MS (2005) Indole Acetic Acid Production by the Indigenous Isolates of Azotobacter and Fluorescent Pseudomonas in the Presence and absence of Tryptophan. Turkish Journal of Biology 29(1): 29-34.

21. Arshad M, Frankenberger WT (1991) Microbial production of plant hormones. Plant and Soil 133 (1): 1-8.

22. Arshad M, Frankenberger WT (1993) Microbial production of plant growth regulators. In: Dekker M (Ed.), Soil Microbial Ecology, New York, USA, pp. 307-347.

23. Sarwar M, Frankenberger WT (1994) Influence of L-tryptophan and auxins applied to the rhizosphere on the vegetative growth of Zea mays L. Plant and Soil 160(1): 97-104.

24. Beattie GA (2006) Plant-associated bacteria: Survey, molecular phylogeny, genomics and recent advances. In: Gnanamanickam SS (Ed.), Plant-Associated Bacteria. Springer. Dordrecht pp. 1-56.

25. Flaishman MA, Eyal ZA, Zilberstein A, Voisard C, Hass D (1996) Suppression of Septoriatritci blotch and leaf rust of wheat by recombinant cyanide producing strains of Pseudomonas putida. Molecular Plant-Microbe Interactions 9 (7): 642-645.

26. Scher FM, Baker R (1982) Effect of Pseudomonas putida and a synthetic iron chelator on induction of soil suppressiveness to Fusarium wilt pathogens. Journal of Phytopathology 72(12): 1567-1573.

27. Masimov IV, Abizgildina RR, Pusenkova LI (2011) Plant growth promoting rhizobacteria as alternative to chemical crop protectors from pathogens. Appl Biochem Microbiol 47(4): 333-345.

28. Neeraja C, Anil K, Purushotham P, Suma K, Sarma P, et al. (2010) Biotechnological approaches to develop bacterial chitinases as a bioshield against fungal diseases of plants. Crit Rev Biotechnol 30(3): 231-241.

29. Kloepper JW, Leong J, Teintze M, Schroth MN (1980) Enhanced plant growth by siderophores produced by plant growth promoting rhizobacteria. Nature 286: 885-886.

30. Neilands JB (1995) Siderophores: Structure and Function of Microbial Iron Transport Compounds. J Biol Chem 270(45): 26723-26726.

31. Whipps JM (2001) Microbial interactions and biocontrol in the rhizosphere. Journal of Experimental Botany 52(1): 487-511. 
32. Crowley DA (2006) Microbial siderophores in the plant rhizosphere. In: Barton LL, Abadía J, (Eds.), Iron Nutrition in Plants and Rhizospheric Microorganisms. Springer, Netherlands, Europe, pp. 169-189.

33. Haas D, Défago G (2005) Biological control of soil-borne pathogens by fluorescent pseudomonads. Nat Rev Microbiol 3(4): 307-319.

34. Pieterse CMJ, Pelt JA, Verhagen BWM, Jurriaan T, Wees SCM, et al. (2003) Induced systemic resistance by plant growth-promoting rhizobacteria. Symbiosis 35 (1-3): 39-54

35. Van Loon LC, Bakker PAHM, Pieterse CMJ (1998) Systemic resistance induced by rhizosphere bacteria. Annu Rev Phytopathol 36: 453-483.

36. Van Peer R, Niemann GJ, Schippers B (1991) Induced resistance and phytoalexin accumulation in biological control of fusarium wilt of carnation by Pseudomonas sp. strain WCS417r. Phytopathology 91: 728-734.

37. Van Loon LC (2000) Systemic induced resistance. In: Slusarenko AJ, Fraser RSS, Van Loon LC (Eds.), Mechanisms of Resistance to Plant Diseases. Kluwer Academic Publishers, Dordrecht, pp. 521-574.

38. Van Wees SCM, De Swart EAM, Van Pelt JA, Van Loon LC, Pieterse CMJ (2000) Enhancement of induced disease resistance by simultaneous activation of salicylate and jasmonate dependent defense pathways in Arabidopsis thaliana. Proc Natl Acad Sci USA 97(15): 8711-8716.

39. Adesemoye A, Torbert H, Kloepper JW (2009) Plant growth-promoting Rhizobacteria allow reduced application rates of chemical fertilizers. Microb Ecol 58(4): 921-929.

40. Hafeez FY, Yasmin S, Ariani D, Mehboob RZY, Malik KA (2006) Plant growth-promoting bacteria as biofertilizer. Agronomy for Sustainable Development 26(2): 143-150.

41. Renseigné N, Han HS, Jung JS, Lee KD (2006) Rock phosphatepotassium and rock-solubilising bacteria as alternative, sustainable fertilisers. Agronomy for Sustainable Development 26(4): 233-240.

42. Vessey JK (2003) Plant growth promoting rhizobacteria as biofertilizers. Plant and Soil 255(2): 571-586.
43. Nakkeeran S, Fernando WGD, Siddiqui ZA (2005) Plant growth promoting rhizobacteria formulations and its scope in commercialization for the management of pests and diseases. In: Siddiqui ZA (Ed.), PGPR: biocontrol and biofertilization. Springer, Dordrecht, pp. 257-296.

44. Chanway CP, Holl FB (1993) First year yield performance of spruce seedlings inoculated with plant growth promoting rhizobacteria. Canadian Journal of Microbiology 39(11): 1084-1088.

45. Zhender GW, Yao C, Murphy JF, Sikora ER, Kloepper JW, et al. (1999) Microbe induced resistance against pathogens and herbivores: evidence of effectiveness in agriculture. In: Agarwal AA, Tuzun S, Bent (Eds.), Induced Plant Defenses Against Pathogens and Herbivores: Biochemistry, Ecology and Agriculture. APS Press, St Paul, Italy, p. 335.

46. Bloemberg GV, Lugtenberg BJJ (2001) Molecular basis of plant growth promotion and biocontrol by rhizobacteria. Curr Opin Plant Biol 4(4): 343-350.

47. Vejan, P, Abdullah R, Khadiran T, Ismail S, Nasrulhaq Boyce A (2016) Role of Plant Growth Promoting Rhizobacteria in Agricultural Sustainability-A Review. Molecules 21(5): 573.

48. Glick BR, Bashan Y (1997) Genetic manipulation of plant growthpromoting bacteria to enhance biocontrol of phytopathogens. Biotechnol Adv 15(2): 353-378.

49. Leveau JHJ (2007) The magic and menace of metagenomics: prospects for the study of plant growth-promoting rhizobacteria. European Journal of Plant Pathology 119 (3): 279-300.

50. Bashan Y, de Bashan LE (2002) Protection of tomato seedlings against infection by Pseudomonas syringae pv. tomato by using the plant growth-promoting bacterium Azospirillumbrasilense. Appl Environ Microbiol 68 (6): 2637-2643.

51. Shanahan P, OSullvan DJ, Simpson P, Glennon JD, OGara F (1992) Isolation and characterization of an antibiotic-like compound from a fluorescent pseudomonad and investigation of physiological parameters influencing its production. Applied and Environmental Microbiology 58(1): 353-358.

\section{Your next submission with Juniper Publishers will reach you the below assets}

- Quality Editorial service

- Swift Peer Review

- Reprints availability

- E-prints Service

- Manuscript Podcast for convenient understanding

- Global attainment for your research

- Manuscript accessibility in different formats

( Pdf, E-pub, Full Text, Audio)

- Unceasing customer service

Track the below URL for one-step submission

https://juniperpublishers.com/online-submission.php 